velopment of a limited program of child protection in connection with certain active and well equipped juvenile courts. The Juvenile Court of Chicago is the best illustration of this tendency. But the juvenile court does not seem the logical place for locating this responsibility. The trend of child protection is toward an early recognition of menacing conditions. Instead of having most of its work adjusted by court action, a well equipped agency requires court action in a decreasing proportion. It is therefore more suitable to have such service rendered by a state agency with county or district units of service.

Just as in the care of dependent children private agencies are rendering a valuable supplemental service wherever a public agency has become active in their care and placement, so in the field of child protection the private agencies can be equally valuable. Such private societies become experimenters, moulders of public opinion and anchors for the maintenance of good public ideals and standards.

The child protection movement of the humane societies has on the whole reached such a precarious position that it is no longer performing its public function in any adequate manner. A few strong societies, chiefly located in large cities, have met the need, but largely with a restricted program. It is of the utmost importance that a new public service in child protection should be created, or, where it has already begun, that it should be extended to give all unfortunate children "a square deal."

\title{
Problems of the Colored Child
}

\author{
By Eugene Kinckue Jones \\ Executive Secretary, National Urban League
}

\begin{abstract}
T public recognition Negroes repre1 sent a class as well as a race, and inherit the status fixed for both class and race divisions of our population. Without affirming any differences in instinct, racial traits or family structure, it is a fact that the problems of the colored child have special and distinct features. His problems are not only the regular and expected problems familiar to social workers given greater volume and intensity because of the economic class to which most colored children belong, but they are these problems further complicated by the circumstances of the Negro's social status, which limits his participation in the normal scheme of adjustment. With more than 70 per cent of the Negro population of ten years of age and over classed as wage earners and
\end{abstract}

over 70 per cent of these wage earners classed as unskilled, Negroes constitute an economic class upon which the burden of child rearing falls hardest. The factor of race intensifies these difficulties by the addition of others.

\section{The Problem of Illiteracy}

The heavy illiteracy rate among Negro children, especially in the South, is frequently taken as an evidence of native backwardness and parental indifference. Granted that both of these alleged causes are factors worthy of consideration, there is still a frightful inadequacy in school facilities which renders them insignificant deterrents by comparison. In 1910 the per cent of Negro illiterates ten years of age and over was 30.4. The percentages varied with the states from 7.9 per cent in 
New York to 38.7 in South Carolina. In these figures is reflected not only the influence of the compulsory education law but the provision, or rather lack of provision, for school facilities as well. For example, whereas New York has compulsory education and provides the same schooling for Negroes as for whites, South Carolina maintains separate schools in which the average yearly expenditure for each white child is $\$ 11.14$ as against $\$ 1.25$ for a colored child. Not only are colored children not urged to attend school, but there are not even enough school buildings to accommodate the colored children who apply for admission. In South Carolina, for example, 39.2 per cent are out of school; in Florida, 47 per cent and in Louisiana, 56.4 per cent. Monroe N. Work, editor of The Negro Year Book, has estimated that on the basis of a nine months' school year it would take a Negro child 22 years in Louisiana, 26 years in Alabama and 33 years in South Carolina to complete an elementary course.

These handicaps are maintained in many sections through the strength of a very common belief that education unfits Negroes for the real labor for which they are destined; that placing them in school would interfere both with the planting and the harvesting of crops and that a more equitable distribution of funds would prove unfair to white tax-payers. These opinions prevail in spite of the very persistent warning of students of the problem that the lack of this schooling and discipline eventually registers itself in dependency, delinquency and crime, which in time entail a greater financial and moral burden on the state.

Educational Problem in the North

In the North there is also an educational problem for colored children. The northward movement of Negroes since slavery and the migration of a half-million Negroes from the South following the outbreak of the World War, have brought thousands of children from the wretched schools of many sections of the South. When reclassified according to the more regular and rigid requirements of northern schools they become over-age pupilslarge, awkward children, ranging in ages from thirteen to eighteen, in classes with children of seven and ten. The severe embarrassments to them increase truancy problems, delinquency and rebellion against home and school discipline. In 1915 a study of five hundred Negro children in the New York public schools, which accommodated the largest number of children whose parents represented the new-comers, revealed that 60.5 per cent of the normal children were over-age for their grade. Some had entered school there for the first time at the ages of twelve and fifteen.

A similar study in 1920 by the Chicago Commission on Race Relations disclosed practically the same condition in Chicago. It was further disclosed, however, that where the children remained and provisions were made for the ungraded pupils, they reached their normal grades in two or three years.

\section{Infant Mortality}

One of the most serious of the special problems is that of reducing the high infant mortality and the prevalence of diseases among colored children; for in this is reflected the conditions under which they must live. The startling disproportion in the infant mortality rate between white and Negro children emphasizes public ignorance and negligence. The infant death rate among Negroes is enormous, in some cities mounting as high as 200 infant deaths per 1,000 births. 
According to figures of the Metropolitan Life Insurance Company, which numbers among its members one-sixth of the entire Negro population in the United States, the Negro death rate among its industrial policy holders is 60 per cent greater than that of the white. Tuberculosis, preëminently a disease of young people, takes a heavy toll. For colored boys insured by the company, this rate is eleven times higher and for colored girls, eight times higher, than the rate for white boys and girls, respectively, of the same age period. Malaria, typhoid fever, syphilis and hookworm also have a disproportionately high sickness and death rate. Louis I. Dublin, Chief Statistician of the Metropolitan Life Insurance Company, in presenting these facts before a conference of the National Urban League, said: "Whether we look at the records of the draft examinations or the figures of mortality among policy holders of the Metropolitan, we find the same fact in evidence; namely, very much higher rates among colored persons from those diseases and conditions which reflect the sanitary conditions of the environment." Practically all of these diseases carrying such a heavy death toll can be checked through closer attention to sanitation, water and milk supply, food handling, garbage disposal, general housing conditions and instruction in personal hygiene. The Metropolitan Life Insurance Company, through encouraging efforts along this line has helped to reduce the death rate among its colored policy holders 9 per cent in eight years.

In New York City alone, the colored infant death rate is 164 deaths per 1,000 births as against 82 per 1,000 births for whites. Twice as many Negro babies die each year as white babies. Although the white population is more than thirty times that of the colored, only seven times as many white boys and girls as colored boys and girls under fourteen years of age, died in New York during 1920.

The general Negro death rate is 21 per thousand as compared with 12.88 per thousand for whites. The expectation of life for white males is 46 years; for Negro males, 37 years; for white females, 52 years; for Negro females, 39 years. Thus the colored child starts out in life under a handicap, as the forces that make for longevity are less apt to be associated with his environment than they are with that of the white child.

These figures suggest, too, a lack of centers for instruction, and lack of participation in the existing agencies designed for this purpose. An intensive campaign of education and a constructive program of service to reduce $\mathrm{Ne}$ gro infant mortality in New York City conducted in 1915 by the various social agencies there, led by the City Department of Health, resulted, in two years' time, in a reduction of Negro infant mortality from 202 per 1,000 births to 173 per 1,000 births.

\section{Colored Children in "Communi- TIEs OF Their Own"}

The obvious difficulties for colored children in connection with the unsanitary quarters in which they are placed are but a part of the problem. Negroes whether in the South or North are, in the main, most effectually isolated from the rest of the community in what many persons are fond of referring to as "communities of their own." Here deterioration is permitted to proceed without the bolstering influence of municipal regulation or private capital. They are the "Negro quarters" and consequently neither force nor merit attention. In many southern cities municipal neglect has become notorious. In northern cities these Negro 
neighborhoods become a dumping ground for the vicious and demoralizing agencies of the city, white as well as black, which seek such places because of their immunity from police interference and effective public protest.

A report of the Chicago Vice Commission, deprecating the forced association of the Negro population with vice, said:

The history of the social evil in Chicago is intimately connected with the colored population. Invariably the largest vice districts have been created in or near settlements of colored people . . . so whenever prostitutes, cadets and thugs were located among white people and had to be moved for commercial or other reasons, they were driven to undesirable parts of the city, the so-called colored residential sections.

No discrimination is exercised in the classification of Negroes. They are all "Negroes" and their children must live within these confines exposed to the undermining influence of the vicious elements of white as well as colored crime and corruption. How active these influences are may best be observed from a study of the juvenile delinquency figures for Negroes.

\section{Problem of Juvenile Delinquency}

In New York, the Negro population is 2.7 per cent of the total population of the city. In 1920 Negroes contributed, however, 3.3 per cent of the juvenile delinquency. In Chicago, the Negro population is 4.5 per cent of the total; in 1920 the Negroes contributed 9.9 per cent of the juvenile delinquency. The officer of a juvenile court in one of the large cities of the north in explaining the higher delinquency rate among Negro children attributed it to "the crime breeding environment in which they have to live," lack of privacy at home, working parents and consequent lack of home supervision.
It should be stated, however, in defense of the normal law-abiding inclination of the colored child that in New York City in 1915, colored children contributed only 1.7 per cent of the total juvenile delinquency while the Negro population was over 2 per cent of the total population of the city.

Social studies recently have been pointing out the relation between delinquency and recreation. The provision of playgrounds and recreation centers in Chicago, for example, reduced delinquency on an average of 44 per cent in the sections over which their influence extended. A Cleveland study discovered that in 75 per cent of the cases of delinquency there was a direct relation between this delinquency and the children's spare time. Thus another problem with Negro children also arises from the general absence of recreational facilities in Negro environment.

The Harlem section of New York City in which more than $75,000 \mathrm{Ne}-$ groes live, has not a single regularly equipped playground. Chicago playgrounds practically skirt the Negro residence areas and in two instances, where large publicly maintained recreation centers are located on the edge of a thickly populated Negro neighborhood, the hostile sentiment and intimidations by whites who visit the centers prevent any use of them by Negro children.

The lack of these provisions is not wholly due to deliberate neglect. Negroes, it must be remembered, usually live in the oldest sections of the city where property values have declined to the size of their purses and where improvements usually have ceased. General community improvements, as well as new recreational centers, are usually placed outside of such sections.

But there are other factors entering 
into the delinquency problem. A prominent cause assigned for delinquency among Negro children is parental neglect. Much of this has been forced by the necessity for both parents to work. The economic struggle thus manifests itself. The wife must supplement the income of the head of the family. In cities where there is lax enforcement of the compulsory education laws or no such laws, the children themselves are pressed into the service of supporting the family. Although this is more patently an economic than a racial question, the pressure of this necessity is more widely diffused among this group because relatively it comprises so large a section of the whole.

\section{Economic OpPoRtunity}

The incentive for continuing in school is much dampened by the apparent lack of opportunity to utilize special training. The doors of industry and business are effectually barred against Negroes except in the lower and more menial branches of work. Persistent effort to extend the field of opportunity by Negro organizations and the necessary admission of Negroes to many coveted positions during the labor scarcity of the early days of the War, have accomplished some advancement in this line but the major difficulties are still but slightly affected. Such was apparent in a study recently made of Negro women in industry in New York City. In the group of colored women studied were many who had completed elementary school courses, high schools and colleges. But whereas of the white and colored women studied 8 per cent more colored had finished elementary school and 9 per cent more had attended high school and college, but few of the colored women had been able to use their special training. The report states:
But few of the specially trained women found work in the trade for which they had been prepared. Occasionally they found their niche through the placement department of the schools and sometimes through personal initiative. Nine trade-trained women entered the Post Office Department under civil service examination. Others, discouraged by seasonal fluctuations and the handicap of color, took places as ladies' maids, elevator operators, etc.

One would have to wait in an employment bureau for many days to hear of even one request for a colored bookkeeper or stenographer. Yet a number of women had been specially trained as stenographers. These finally entered factories doing unskilled, monotonous work-their spirits broken and hopes blasted because they had been obliged to forfeit their training on account of race prejudice. School teachers were among these new recruits in both skilled and unskilled industries. Some had been grade teachers, two had taught in high school, and one had been a supervisor in a normal school.

\section{Suggestions of Other Special Difficulties}

It is apparent that problems of the Negro child are special only in so far as the general attitude of the public, influenced by traditional racial sentiment, has operated to make them so. When Negroes are isolated from the rest of the community as a group different and distinctive with a mode of treatment for them already outlined, neglect and indifference are expected. For they are more an appendix than a functional part of the community. Thus it is that general social organizations as a rule conduct their activities over the heads of the Negro community, which is by no means separate and distinct by choice.

In Cincinnati, for example, where the Negro juvenile delinquency rate is 12 per cent of the total while the Negro population is only 7 per cent, probation work touched but fifteen Negro 
cases. The Juvenile Protective Society of Chicago does not cover the areas of Negro residence. Movements like the Boy Scouts, Girl Scouts, Brotherhood Republic-character builders of youth -indifferently touch the lives of Negro youths.

When the seriousness of Negro cases reaches the point of demanding institutional care, other difficulties appear. In most northern communities colored and white children are accepted by the same institutions. Usually the proportion of Negroes is smaller, both in proportion to the Negro population and in proportion to the cases of Negroes requiring institutional care. For Negro feeble-minded there is little care in the North and practically none in the South. The superintendent of one northern institution for the care of feeble-minded expressed a view that many Negro children thought to be feeble-minded were not really so, but only appeared so by comparison with white standards! How far this misapprehension, undoubtedly shared by others, has operated to affect the volume of present Negro feeble-minded in institutions, it is impossible to say.

Commenting on the alarming inade- quacies throughout the country, and especially in the South, Hastings $\mathbf{H}$. Hart, Director of the Department of Child-Helping of the Russell Sage Foundation, says:

This is a matter of great moment because the neglected feeble-minded colored children swell the ranks of paupers, criminals and vicious persons, and also spread social disease. It appears to me extremely important that the southern people should become aware of the fact that in neglecting the colored children they are hazarding the interest of the white population almost as much as that of the Negro population.

Appeals for participation by Negroes in social service programs have been directed on the basis of experiments demonstrating that where Negro children are provided with the same prophylactics their health, crime, illiteracy and dependency rates are reduced to proportions comparable with those of white children. The crux of the problem, however, is the unyielding bloc of public disinterest and opposition which holds fast to traditional restraints, both economic and sentimental, and which makes the Negro's struggle for existence more severe.

\section{Helping the Farmer Through His Children $\$ 100,000,000$ Worth of Children on the Farm}

By Owen R. Lovejox, LL.D.

General Secretary, National Child Labor Committee

T THE National Child Labor Committee's interest in the country child is no new thing, and yet we still find people to whom it is a shock to discover that farmwork may be considered child labor. For in the minds of many people those words, "child labor," still call up only the pathetic image of a haggard and wizened child of seven years, or it may be ten or twelve, dragging an enormous dinner pail into a factory at dawn. And it is true that for years the plight of the factory child, or at least the child engaged in those pursuits commonly classified as industrial, has been emphasized almost to the exclusion of all other children. But this does not necessarily in- 